Download

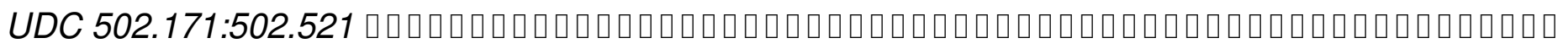

//

doi

org

$/ 10.17721 / 2308-135$

$X$

.2020 .55 .

50

56

Melniychuk Mikhail Myxajlovych, Ph.D in Geographical Sciences, Associate Professor, Eastern European National University named by Lesia Ukrainka, Lutsk, Ukraine,

e

mail

:

Yaromenko_ov@ukr.net

Akhmedov Bogdan Myxajlovych, Eastern European National University named by Lesia Ukrainka, Lutsk, Ukraine, e-mail: Yaromenko_ov@u kr.net 


\section{THE STATE OF LAND RESOURCES AS PART OF THE LAND FUND OF THE VOLYN REGION IS INVESTIGATED}

The aim is to analyze land resources as part of the land fund of the Volyn region. A profound study of land resources in the region on such components as land types, quantitative and qualitative indicators to determine the state of land resources at the regional level is done. General scientific and static methods, methods of system and structural analysis, comparative geographical and graphic methods are applied. Regional statistics are processed.

The results are shown. The essence of land resources as a part of the country's land fund is revealed. The land fund of the Volyn region is covered (as of January 1, 2019, is 2014.4 thousand hectares), $52 \%$ of which is occupied by agricultural land, which indicates a high level of agricultural land development and excessive plowing of its territory. We observe different internal agro-development of the territory of the region in accordance with its landscape differences. The share of the main components of agricultural land in the Volyn region is $33 \%$. The changes in the structure of land resources of the Volyn region are evidenced by the fact that the disturbed lands, which lost their economic and environmental value amounted to 5.85 thousand hectares. There is an increase in the share of unproductive and degraded lands. $87.4 \%$ of the total land area of the region is unproductive (2018). In the structure of degraded lands of the Volyn region, lands with acid soils are widespread (12.4\% of the total area). The indicator of humus content in soils is important when assessing land resources. The weighted average humus index in the soils of the Volyn region was $1.56 \%$. The application of mineral and organic fertilizers in agricultural enterprises of the region has decreased. The state of land resources of the Volyn region is characterized. The humus condition of soils deteriorates, the supply of nutrients decreases, acidity increases and, as a consequence, their fertility decreases. Rational use of land resources requires the prevention of adverse physical and geographical processes.

Scientific novelty. The state of land resources by their structure, quantitative and qualitative indicators on the example of the Volyn region is revealed.

Practical significance. The results of the studies reveal the state of land resources of the Volyn 
region. The results can be used to determine the potential productivity of land resources in the region. The level of the maximum possible rational efficiency of their usage from the point of view of management is determined.

Key words: land resources, agricultural lands, soil, region.

\section{References}

1.Babych A. O.Svitovi zemel $\square$ ni, prodovol $\square$ chi i kormovi resursy / A.O. Babych. $-K$.: Vydavnytstvo «Ahrarna nauka», 1996. - $570 \mathrm{~s}$.

2.Ekolohichnyy pasport Volyns $\square$ koyi oblast $\square$ za 2018 r. - [Elektronyy resurs]. - Rezhym dostupu: https://voladm.gov.ua/article/ekologichniy-pasport-volinskoyi-oblasti-za-2018-rik/.

3.Zakon Ukrayiny vid 19.06.2003 № 962 «Pro okhoronu zemel[». - [Elektronyy resurs]. Rezhym dostupu: https://zakon.rada.gov.ua/laws/show/962-15.

4. Kornus A. Otsinka stanu zemel $\square$ nykh resursiv Sums $\square$ koyi oblasti / A. Kornus. // Ratsional $\square$ ne pryrodokorystuvannya i okhorona pryrody. Naukovi zapysky. - №1. - 2012. - S.215-219.

5.Mol chak YA. O. Konstruktyvno-heohrafichnyy analiz ta otsinka pryrodnoho ahroresursnoho potentsialu Volyns $\square$ koyi oblasti : monohrafiya / YA. O., Mol $\square$ chak, A . H. Potapova. - Luts $\square$ k : RVV LNTU, 2010. - $215 \mathrm{~s}$.

6.Pavlovs $\square$ ka T. S. Struktura zemel $\square$ nykh uhid $\square$ v landshaftno- ekolohichniy orhanizatsiyi terytoriyi Volyns $\square$ koyi oblasti / T. S. Pavlovs $\square$ ka // Heopolytyka y ékoheodynamyka rehyonov. 2014. - № 2. - S. 697-704. 
7.Polyans $\square$ kyy S. V. Otsinka efektyvnosti vykorystannya i zberezhennya zemel $\square$ nykh resursiv Volyns $\square$ koyi oblasti / S. V. Polyans $\square$ kyy., T. O. Knyaz $\square$ kova T. O. // Ekonomichni nauky. Seriya «Ekonomichna teoriya ta ekonomichna istoriya»: Zbirnyk naukovykh prats $\square$ LNTU. - Luts $\square$ k : RVV LNTU, 2011. - Vyp. 8 (32). - S. 292-300.

8.Statystychnyy shchorichnyk Volyn $\square$. - 2010. Holovnoho upravlinnya statystyky u Volyns $\square$ kiy oblasti. za redaktsiyeyu M.I. Motyl[. - Luts $\square$ k. - 2011. - 569 s.

Надійшла до редколегії/Received Editorial Board 12.05.2020 